\title{
The Cohesive Properties of Variants of Neisseria gonorrhoeae Strain P9: Specific Pilus-mediated and Non-specific Interactions
}

\author{
By T. J. TRUST, ${ }^{1}$ P. R. LAMBDEN ${ }^{2 *}$ AND P. J. WATT ${ }^{2}$ \\ ${ }^{1}$ Department of Biochemistry and Microbiology, University of Victoria, \\ Victoria, British Columbia, Canada V8W 2 Y 2 \\ 2 Department of Microbiology, Southampton University Medical School, \\ Southampton General Hospital, Tremona Road, Southampton SO9 $4 X Y$
}

(Received 9 January 1980)

\begin{abstract}
The cohesive properties of virulent pilated Neisseria gonorrhoeae strain $\mathrm{P} 9\left(\mathrm{P}^{++}\right)$have been compared with those of a non-pilated isogenic variant $\left(\mathrm{P}^{-}\right)$possessing the same outer membrane components. The binding of $\mathrm{P}^{++}$gonococci to buccal epithelial cells was dependent on $\mathrm{pH}$, with an optimum at $\mathrm{pH} 6.5$ to $7 \cdot 0$. This adhesion was markedly inhibited by treatment of the buccal epithelial cells with a neuraminidase/exoglycosidase mixture. In contrast, the binding of $\mathrm{P}^{++}$gonococci to erythrocytes was unaffected by $\mathrm{pH}$. A possible explanation is that pili bind to a carbohydrate receptor present on buccal epithelial cells but lacking on erythrocytes. The adhesion of $\mathbf{P}^{-}$gonococci to erythrocytes and to buccal epithelial cells was unaffected by $\mathrm{pH}$ but enhanced by treatment of the cells with neuraminidase or periodate. Presumably, neuraminic acid residues on host cell surface carbohydrates inhibit adhesion. The finding that $\mathbf{P}^{-}$gonococci bind to amphipathic gels suggests hydrophobic interactions as a possible non-specific mechanism attaching $\mathrm{P}^{-}$gonococci to host cell surfaces.
\end{abstract}

\section{INTRODUCTION}

The mucosal surfaces of man are the natural habitat of Neisseria gonorrhoeae. A critical determinant of the ability to grow in such an hostile environment is the possession of a mechanism for anchorage to the mucosal cells whose surfaces are continuously washed by flows of mucus and other secretions. This adhesion to the host cell must, of necessity, be mediated by macromolecules expressed at the surface of the gonococcus. The function of the outer envelope in such Gram-negative bacteria is complex (DiRienzo et al., 1978) with different components being involved in structural integrity, in the formation of non-specific diffusion pores as well as in uptake systems for iron, sugars, vitamins, etc. For gonococci, this is further complicated by the need for surface structures to form a diffusion barrier protecting the vulnerable cytoplasmic membrane from the lytic action of antibody and complement (Ward et al., 1978). Clearly, outer membrane molecules with different functions will contribute to the physical characteristics of the gonococcal surface and by their effects on charge density, hydrophobicity and polymer interactions influence the cohesive properties of specific mediators of adhesion.

Pili, protein filaments protruding up to $\mathrm{I} \mu \mathrm{m}$ from the gonococcal surface, facilitate the binding of gonococci to cells in tissue culture, to human sperm and to Fallopian tube organ cultures (Buchanan, 1977). However, pili are not the sole effectors of gonococcal adhesion since outer membrane proteins have been shown to mediate gonococcal attachment to buccal mucosal cells, erythrocytes and polymorphonuclear (PMN) leukocytes (Lambden et al., 1979). In order to identify the function of pili in gonococcal attachment and investigate 
the likely effect of outer membrane components on pilus-mediated adhesion we have compared the cohesive properties of the virulent, pilated gonococcus strain P9 with a non-pilated variant, both of which possess only protein I and lipopolysaccharide as major components of the outer membrane.

\section{METHODS}

Bacterial strains and growth conditions. Neisseria gonorrhoeae strain P9 variants were grown on clear typing medium as previously described (Lambden et al., 1979). Colonies of transparent pilated $\mathrm{P}^{++}(\mathrm{P9}-2)$ (Lambden et al., 1980) and non-pilated $\mathrm{P}^{-}$(P9-1) variants were picked, purified by single colony isolation and stored in liquid nitrogen.

${ }^{3} \mathrm{H}$-Labelled gonococci were harvested from plates containing $25 \mu \mathrm{Ci} \mathrm{D}-\left[1{ }^{3} \mathrm{H}\right] \mathrm{glucose} \mathrm{ml}^{-1}[500 \mathrm{mCi}$ $\mathrm{mmol}^{-1}\left(18.5 \mathrm{GBq} \mathrm{mmol}^{-1}\right)$; The Radiochemical Centre, Amersham] into complete Dulbecco phosphatebuffered saline $\mathrm{pH} 7 \cdot 4$ (PBS; Oxoid). The gonococci were suspended by vortex mixing and aggregates were removed by centrifugation at $150 \mathrm{~g}$ for $1 \mathrm{~min}$. The resulting gonococcal suspensions were diluted to a cell density of $2.8 \times 10^{7}$ colony-forming units (c.f.u.) $\mathrm{ml}^{-1}$ in Basal Medium Eagle (Modified) with Hanks' balanced salts (Flow Laboratories) buffered with $0.05 \mathrm{M}-N$-2-hydroxyethylpiperazine- $N^{\prime}$-2-ethanesulphonic acid (HEPES) to $\mathrm{pH} 7 \cdot 4$ (TCM).

Determination of gonococcal attachment. Gonococcal attachment to host cells was determined as described previously (Lambden et al., 1979). Buccal epithelial cells and erythrocytes were collected from volunteers, washed three times in PBS and finally suspended at a packed cell volume (p.c.v.) of $10 \%$ in TCM. ${ }^{3} \mathrm{H}$-Labelled gonococci and host cells were incubated together with gentle shaking at $37^{\circ} \mathrm{C}$. Host cells with adherent gonococci were separated from free gonococci by centrifugation through a cushion of dextran. The pellet was recovered following aspiration of the dextran containing unattached gonococci and finally counted in a Packard TriCarb liquid scintillation counter. Before estimation of the numbers of bound gonococci, erythrocytes were lysed with $1 \mathrm{M}-\mathrm{NaOH}$ and decolorized by incubation with $30 \%(\mathrm{w} / \mathrm{v}) \mathrm{H}_{2} \mathrm{O}_{2}$ at $50{ }^{\circ} \mathrm{C}$ for $1 \mathrm{~h}$. Attachment of gonococci to various alkyl-substituted agarose gels (Miles Laboratories Ltd, Stoke Poges, Slough) was performed using $20 \%$ (v/v) gel suspensions.

Under control conditions with tests repeated 16 times the mean value for binding $\mathrm{P}^{++}$gonococci to octylagarose was $11.3 \%$ with a standard deviation of $0.59 \% ; \mathrm{P}^{-}$gonococci showed $10.5 \%$ binding with a standard deviation of $0.4 \%$. Experiments using gonococci at different concentrations $\left(1 \times 10^{7}\right.$ to $1 \times 10^{8}$ c.f.u. $\left.\mathrm{ml}^{-1}\right)$ and varying the binding time demonstrated that under standard experimental conditions binding sites for $\mathrm{P}^{++}$and $\mathrm{P}^{-}$gonococci on alkyl-agarose gels were unsaturated.

Experiments were performed to study the effect on gonococcal attachment of (i) time; (ii) temperature; (iii) $\mathrm{pH}$ (determined in TCM adjusted to the desired $\mathrm{pH}$ by the addition of $1 \mathrm{M}$-Tris or $1 \mathrm{M}$-maleic acid); (iv) the cations $\mathrm{Ca}^{2+}, \mathrm{Mg}^{2+}, \mathrm{Mn}^{2+}$ and $\mathrm{Fe}^{3+}$ (using host cells washed in PBS containing 5 mM-EDTA); (v) the amino acids histidine, phenylalanine, tyrosine and tryptophan at a final concentration of $1 \mathrm{~mm}$; (vi) the sugars lactose, melibiose, mannose, $\alpha$-methyl mannoside, galactose, $\alpha$-methyl galactoside, $\beta$-methyl galactoside, fucose, $N$-acetylglucosamine and $N$-acetylgalactosamine; (vii) the gangliosides GM1, GD1a, GT1 and mixed; and (viii) several substituted agarose gels.

Periodate oxidation of gonococci and host cells. Gonococci were harvested from solid medium into $0.1 \mathrm{M}$ sodium acetate buffer pH 5.5 containing $9 \mathrm{mg} \mathrm{NaCl} \mathrm{ml}^{-1}$ and $1 \mathrm{mg} \mathrm{CaCl}_{2} \mathrm{ml}^{-1}$ to give a final cell density of about $1 \times 10^{8}$ to $5 \times 10^{8}$ c.f.u. $\mathrm{ml}^{-1}$. The gonococcal suspension was diluted with an equal volume of acetate buffer containing $20 \mathrm{~mm}$-sodium periodate and incubated with gentle shaking for $30 \mathrm{~min}$ at $4{ }^{\circ} \mathrm{C}$. The organisms were then washed twice, resuspended in $0.1 \mathrm{M}$-Tris/maleate $\mathrm{pH} 7.4$ containing $9 \mathrm{mg} \mathrm{NaCl} \mathrm{ml}{ }^{-1}$ and $1 \mathrm{mg} \mathrm{CaCl} \mathrm{ml}^{-1}$, and added to an equal volume of the same buffer containing $10 \mathrm{~mm}$-sodium borohydride. After incubation at $4{ }^{\circ} \mathrm{C}$ for $30 \mathrm{~min}$, the gonococci were washed twice in PBS and diluted to the required cell density in TCM. Control organisms were treated in an identical manner except that sodium periodate was omitted.

Buccal epithelial cells and erythrocytes were subjected to periodate oxidation by the above procedure at a p.c.v. of $1 \%$ and $4 \%$, respectively.

Enzyme treatment of host cells. (i) Erythrocytes were treated with trypsin as follows: erythrocytes were recovered from fresh heparinized blood by centrifugation, washed three times in PBS and resuspended in PBS to a p.c.v. of $10 \%$. Trypsin (EC 3.4.21 .4; Sigma Type III) was added to the erythrocyte suspension to give a final concentration of $1 \mathrm{mg} \mathrm{ml}^{-1}$ and the cells were incubated for $1 \mathrm{~h}$ at room temperature. Finally, cells were washed twice and resuspended to the required cell density in TCM. (ii) Buccal epithelial cells and erythrocytes were treated with neuraminidase as follows: buccal epithelial cells and erythrocytes were suspended at a p.c.v. of $10 \%$ in $0.05 \mathrm{M}$-sodium acetate buffer pH 5.5 containing $9 \mathrm{mg} \mathrm{NaCl} \mathrm{ml}^{-1}$ and $1 \mathrm{mg}$ $\mathrm{CaCl}_{2} \mathrm{ml}^{-1}$. Neuraminidase (EC 3 2.1.18; Behring) was added to give $0 \cdot 1 \mathrm{U} \mathrm{ml}^{-1}$ and the cells were incubated at $37^{\circ} \mathrm{C}$ for $1 \mathrm{~h}$. The release of $\mathrm{N}$-acetylneuraminic acid was monitored using the thiobarbituric acid method 
(Waravdekar \& Saslaw, 1959). The cells were finally washed and resuspended in TCM. (iii) Buccal epithelial cells were treated with mixed exoglycosidases (Miles Laboratories) at a final concentration of 1 or $10 \mathrm{mg} \mathrm{ml}^{-1}$ in $0.05 \mathrm{M}$-sodium acetate buffer $\mathrm{pH} 5 \cdot 5$. Neuraminidase $\left(0 \cdot 1 \mathrm{U} \mathrm{ml}^{-1}\right)$ was also added to the exoglycosidase mixture as this activity was absent from the preparation. The exoglycosidase preparation contained the following enzyme activities: $\alpha$ - and $\beta$-N-acetylhexosaminidase, $\alpha$ - and $\beta$-mannosidase, $\alpha$ - and $\beta$-glucosidase, $\alpha$ - and $\beta$-galactosidase, $\alpha$-L-fucosidase and $\beta$-xylosidase.

Preparation of ${ }^{125} I$-labelled polysaccharide-methyl-bovine serum albumin conjugate. Lipopolysaccharide (LPS) from $N$. gonorrhoeae P9 was prepared from a cholate extract of outer membrane material (Heckels, 1977). Core oligosaccharide was prepared by partial acid hydrolysis of LPS according to the method of Perry et al. (1975) and keto groups were reduced with sodium borohydride. Reduced P9 core oligosaccharide was coupled through free carboxyl groups on 2-keto-3-deoxyoctonic acid (KDO) to free amino groups on the methyl ester of bovine serum albumin (methyl-BSA; Sigma) using 1-ethyl-3-(3-dimethylaminopropyl)carbodiimide. $\mathrm{HCl}$ (EDC). Reduced core oligosaccharide $(10 \mathrm{mg})$ was mixed with methyl-BSA $(10 \mathrm{mg})$ in $2 \mathrm{ml}$ water. $\mathrm{EDC}(50 \mathrm{mg})$ was added to the mixture and the $\mathrm{pH}$ was adjusted to $4 \cdot 5$. The $\mathrm{pH}$ was maintained at 4.5 for $1 \mathrm{~h}$ and then the reaction mixture was allowed to stand at room temperature overnight. The methylBSA-oligosaccharide conjugate was removed from the reaction products and uncoupled polysaccharide by chromatography on a Sephadex G-50M column $(1.5 \times 35 \mathrm{~cm})$. The amount of carbohydrate associated with the protein peak was determined by the phenol/sulphuric acid method (Dubois et al., 1956). The analysis of the conjugate showed a ratio of $5 \mathrm{~mol}$ polysaccharide to $1 \mathrm{~mol}$ methyl-BSA. Samples of the P9 polysaccharide-methyl-BSA conjugate and methyl-BSA were then radiolabelled with ${ }^{125} \mathrm{I}$ using the chloramine-T method (Greenwood et al., 1963).

Gangliosides. The gangliosides GM1, GD1a, GT1 and mixed gangliosides were a generous gift of W. E. van Heyningen (Sir William Dunn School of Pathology, University of Oxford). Gangliosides were dissolved in chloroform/methanol $(1: 1, \mathrm{v} / \mathrm{v})$ and dried to a film in a flask under a stream of $\mathrm{N}_{2}$. The ganglioside film was shaken with a small volume of TCM and the resulting suspension was sonicated (MSE, $100 \mathrm{~W}$ ) for 2 min under a stream of $\mathrm{N}_{2}$. The ganglioside micelles thus produced were used in attachment-inhibition experiments.

\section{RESULTS}

\section{Factors affecting gonococcal attachment}

The time course for gonococcal attachment to buccal epithelial cells is shown in Fig. 1. The binding of both pilated $\left(\mathrm{P}^{++}\right)$and non-pilated $\left(\mathrm{P}^{-}\right)$variants was essentially maximal after $4 \mathrm{~h}$, although the overall binding of the $\mathrm{P}^{++}$variant was at least twice that of the $\mathrm{P}^{-}$ variant. This adhesion was temperature-dependent. The binding of $\mathrm{P}^{++}$organisms decreased from $17 \%$ at $37{ }^{\circ} \mathrm{C}$ to $8.7 \%$ at $4{ }^{\circ} \mathrm{C}$, while $\mathrm{P}^{-}$organisms showed a decrease from $8.7 \%$ binding at $37^{\circ} \mathrm{C}$ to $6.3 \%$ binding at $4{ }^{\circ} \mathrm{C}$.

The influence of $\mathrm{pH}$ on gonococcal attachment to buccal epithelial cells produced striking differences between $\mathrm{P}^{++}$and $\mathrm{P}^{-}$organisms (Fig. 2). The binding of $\mathrm{P}^{++}$organisms increased almost fivefold over the $\mathrm{pH}$ range $4 \cdot 5$ to $7 \cdot 0$, with a decrease in attachment above $\mathrm{pH} 7 \cdot 0$, whereas the binding of $\mathrm{P}^{-}$organims was progressively reduced as the $\mathrm{pH}$ was raised from 4.5 to $7 \cdot 5$. Interestingly, at $\mathrm{pH} 4.5$ the binding of $\mathrm{P}^{-}$organisms was always greater than that of $\mathrm{P}^{++}$organisms. In contrast, the attachment of gonococci to erythrocytes was totally unaffected by $\mathrm{pH}$ over the range tested (Fig. 2), demonstrating a clear difference in the mechanisms of attachment to the two host cells. As with buccal epithelial cells, $\mathrm{P}^{++}$organisms showed a twofold greater binding to erythrocytes than did $\mathrm{P}^{-}$organisms. The binding of gonococci to EDTA-washed host cells was not dependent on the presence of divalent cations in the attachment medium. The addition of either $5 \mathrm{~mm} \mathrm{Ca}{ }^{2+}, \mathrm{Mg}^{2+}$ or $\mathrm{Mn}^{2+}$ increased the binding of the $\mathrm{P}^{++}$variant from 10 to $13 \%$ but was without effect on the $\mathrm{P}^{-}$variant. The presence of $5 \mathrm{mM}-\mathrm{Fe}^{3+}$ caused marked aggregation of $\mathrm{P}^{++}$gonococci preventing meaningful assessment of the effect of $\mathrm{Fe}^{3+}$ on the binding of gonococci to host cell membranes.

\section{Nature of the attachment mechanism}

A variety of compounds was tested for their ability to inhibit attachment of gonococci to host cells. The amino acids histidine, phenylalanine, tyrosine and tryptophan at a final concentration of $1 \mathrm{~mm}$ had no effect on gonococcal binding to host cells, and neither did 


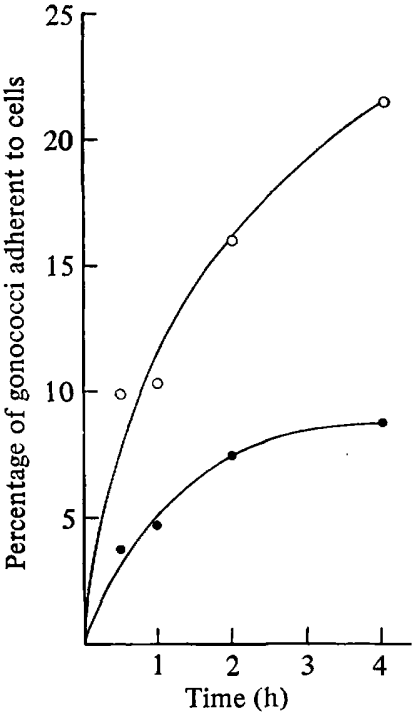

Fig. 1

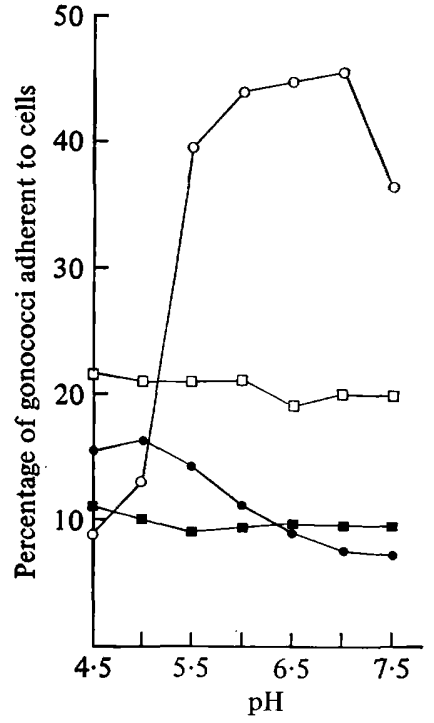

Fig. 2

Fig. 1. Comparison of the ability of pilated $\left(\mathrm{P}^{++}, 0\right)$ and non-pilated $\left(\mathbf{P}^{-}, \mathbf{O}\right)$ variants of $N$. gonorrhoeae to bind to buccal epithelial cells.

Fig. 2. Effect of $\mathrm{pH}$ on the attachment of pilated $\left(\mathrm{P}^{++}\right)$and non-pilated $\left(\mathrm{P}^{-}\right)$variants of $N$. gonorrhoeae to human cells: attachment of $\mathrm{P}^{++}$to buccal epithelial cells $(O)$ and to erythrocytes $(\square)$; attachment of $\mathbf{P}^{-}$to buccal epithelial cells $(\mathbf{O})$ and to erythrocytes $(\square)$.

the sugars lactose, melibiose, mannose, $\alpha$-methyl mannoside, galactose, $\alpha$-methyl galactoside, $\beta$-methyl galactoside, fucose, $N$-acetylglucosamine and $N$-acetylgalactosamine.

The effect of gangliosides on the attachment of intact gonococci to buccal epithelial cells is shown in Table 1. Clearly, binding of the $\mathrm{P}^{-}$variant was unaffected by the presence of gangliosides in the attachment medium. The $\mathrm{P}^{++}$variant, however, aggregated much more in the presence of ganglioside GT1 which resulted in an apparent inhibition of binding to buccal epithelial cells when the control counts were subtracted from the test.

\section{Non-specific interactions}

The extent to which hydrophobic interactions influence binding of intact gonococci was measured using agarose gels, substituted with non-polar ligands (Table 2). The degree of adsorption to the gels was similar for both $\mathrm{P}^{++}$and $\mathrm{P}^{-}$variants, both demonstrating a marked increase in attachment according to the chain length of the alkyl substituent.

Non-specific interactions between charged groups were investigated by measuring binding to CM Bio-gel A and DEAE Bio-gel A (Bio-Rad) over the $\mathrm{pH}$ range 5.0 to 7.5. In each case, binding over the entire $\mathrm{pH}$ range was constant and there was no apparent difference between $\mathrm{P}^{++}$and $\mathrm{P}^{-}$organisms, although attachment of gonococci was greater to diethylaminoethyl groups on DEAE Bio-gel (16.6\%) than to carboxyl groups on CM Bio-gel $(0 \cdot 8 \%)$.

\section{Nature of the gonococcal adhesin}

In an attempt to understand the molecular basis of the attachment mechanism, the gonococcal surface was modified by a variety of agents (Table 3 ). Ultraviolet irradiation of whole gonococci did not affect the binding of the $\mathrm{P}^{-}$variant whereas the attachment of the $\mathrm{P}^{++}$ variant was decreased by some $50 \%$, presumably due to denaturation of surface pili. Modification of surface carbohydrates was achieved using glycosidases and by periodate oxidation followed by borohydride reduction. Binding of the $\mathrm{P}^{-}$variant was little affected although 
Table 1. Effect of gangliosides on the binding of ${ }^{3} \mathrm{H}$-labelled pilated $\left(\mathrm{P}^{++}\right)$and non-pilated $\left(\mathrm{P}^{-}\right)$ variants of $N$. gonorrhoeae strain $\mathrm{P} 9$ to buccal epithelial cells

\begin{tabular}{|c|c|c|c|c|}
\hline \multirow[b]{2}{*}{ Treatment* } & \multicolumn{2}{|c|}{ Percentage of $\mathrm{P}^{++}$variants sedimenting } & \multicolumn{2}{|c|}{ Percentage of $\mathrm{P}^{-}$variants sedimenting } \\
\hline & With buccal cells & Alone & With buccal cells & Alone \\
\hline $\begin{array}{l}\text { None } \\
\text { GM1 } \\
\text { GD1a } \\
\text { GT1 }\end{array}$ & $\begin{array}{l}21 \cdot 1 \\
23 \cdot 8 \\
23 \cdot 3 \\
28 \cdot 0\end{array}$ & $\begin{array}{r}5 \cdot 7 \\
4 \cdot 1 \\
9 \cdot 1 \\
21 \cdot 5\end{array}$ & $\begin{array}{l}8 \cdot 8 \\
8 \cdot 4 \\
7 \cdot 2 \\
7 \cdot 5\end{array}$ & $\begin{array}{l}0.6 \\
0.6 \\
0.8 \\
0.9\end{array}$ \\
\hline
\end{tabular}

* Gonococci were exposed to ganglioside micelles at a concentration of $120 \mu \mathrm{g} \mathrm{ml}^{-1}$.

Table 2. Comparative adsorption to hydrophobic gels of ${ }^{3} H$-labelled pilated $\left(\mathrm{P}^{++}\right)$ and non-pilated $\left(\mathrm{P}^{-}\right)$variants of $N$. gonorrhoeae strain $\mathrm{P} 9$

Values given are the percentage of organisms recovered with the gel beads and are the mean of several experiments.

\begin{tabular}{ccccccc} 
& \multicolumn{6}{c}{ Non-polar ligand on agarose gel } \\
\cline { 2 - 5 } Variant & None & Ethyl & Butyl & Hexyl & Octyl & Decyl \\
$\mathrm{P}^{-}$ & $1 \cdot 2$ & 4.4 & 4.1 & 7.9 & 10.5 & 14.1 \\
$\mathrm{P}^{++}$ & $1 \cdot 1$ & 4.1 & 3.7 & 9.7 & 11.3 & 15.9
\end{tabular}

Table 3. Effect of modifying gonococcal surface components on the binding of ${ }^{\mathbf{3}} \mathrm{H}$-labelled pilated $\left(\mathrm{P}^{++}\right)$and non-pilated $\left(\mathrm{P}^{-}\right)$variants of $N$. gonorrhoeae strain $\mathrm{P} 9$ to buccal epithelial cells

$\begin{array}{lcc}\text { Treatment } & \overbrace{\text { Variant } \mathrm{P}^{++}}^{\text {Relative binding* }} & \text { Variant } \mathbf{P}^{-} \\ \text {None } & 100 & 32 \\ \text { U.v. irradiationt } & 48 & 33 \\ {\text { Periodate } / \mathrm{NaBH}_{4}}_{\mathrm{NaBH}} \text { control } & 30 & 42 \\ \mathrm{NaH}_{4} & 100 & 39\end{array}$

* To facilitate comparison of results the percentage binding of untreated $\mathrm{P}^{++}$variants to buccal epithelial cells $(31 \%)$ is expressed as 100 .

$\dagger$ U.v. irradiation: $254 \mathrm{~nm}$ at $5 \mathrm{~cm}\left(1240 \mu \mathrm{W} \mathrm{cm} \mathrm{cm}^{-2}\right)$ for $1 \mathrm{~h}$.

borohydride reduction resulted in a small increase in attachment. In contrast, the binding of the $\mathrm{P}^{++}$variant to buccal epithelial cells was greatly decreased $(70 \%)$ to the level obtained for the $\mathrm{P}^{-}$variant. Attempts to block pilus-mediated adhesion using the galactose-specific lectin Ricin I were unsuccessful. In the presence of $0.08 \mu \mathrm{M}$-Ricin I the apparent binding of $\mathrm{P}^{++}$to cells was increased from 13 to $24 \%$ presumably due to cross-linking by the multivalent lectin.

The possibility that lipopolysaccharide (LPS) in the gonococcal outer membrane was contributing to the attachment process was examined using a gonococcal core oligosaccharide-methyl-BSA conjugate. No significant binding of the conjugate to buccal cells was detected over a 100 -fold range of concentration $\left(1\right.$ to $\left.100 \mu \mathrm{g} \mathrm{ml}^{-1}\right)$. Approximately $3 \%$ of the added conjugate was recovered with the buccal epithelial cells, whereas a greater proportion $(10 \%)$ of the unsubstituted methyl-BSA was found attached under identical conditions. Presumably, hydrophobic interactions accounted for the binding of ${ }^{125}$ I-labelled methyl-BSA to buccal epithelial cells and this was significantly impaired in the core oligosaccharide-methyl-BSA conjugate. 
Table 4. Effect of modifying the surface carbohydrates of buccal epithelial cells on the binding of ${ }^{3} \mathrm{H}$-labelled pilated $\left(\mathrm{P}^{++}\right)$and non-pilated $\left(\mathrm{P}^{-}\right)$variants of $N$. gonorrhoeae strain $\mathrm{P} 9$

\begin{tabular}{lcc}
$\quad$ & \multicolumn{2}{c}{ Relative binding* } \\
Treatment & $\overbrace{\text { Variant } \mathrm{P}^{++}}^{\text {Variant } \mathrm{P}^{-}}$ & 35 \\
None & 100 & 30 \\
Neuraminidase & 92 & 34 \\
Neuraminidase plus exoglycosidase $\left(1 \mathrm{mg} \mathrm{ml}^{-1}\right)$ & 73 & 35 \\
Neuraminidase plus exoglycosidase $\left(10 \mathrm{mg} \mathrm{ml}^{-1}\right)$ & 22 & 35 \\
Periodate/NaBH $_{4}$ & 100 & 31 \\
$\mathrm{NaBH}_{4}$ control & 100 &
\end{tabular}

* To facilitate comparison of results the percentage binding of $\mathrm{P}^{++}$variants to untreated buccal epithelial cells $(26.6 \%)$ is expressed as 100 .

Table 5. Effect of modifying the erythrocyte surface on the binding of ${ }^{3} \mathrm{H}$-labelled pilated $\left(\mathrm{P}^{++}\right)$ and non-pilated $\left(\mathrm{P}^{-}\right)$variants of $N$. gonorrhoeae strain $\mathrm{P} 9$

\begin{tabular}{lcc} 
& \multicolumn{2}{c}{ Relative binding* } \\
\cline { 2 - 3 } \multicolumn{1}{c}{ Treatment } & Variant $\mathrm{P}^{++}$ & Variant $\mathrm{P}^{-}$ \\
None & 100 & 64 \\
Trypsin & 114 & 114 \\
Neuraminidase & 107 & 105 \\
${\text { Periodate } / \mathrm{NaBH}_{4}}_{\mathrm{NaBH}_{4} \text { control }}$ & 56 & 60 \\
& 104 & 69
\end{tabular}

* To facilitate comparison of results the percentage binding of $\mathrm{P}^{++}$variants to untreated erythrocytes $(37 \%)$ is expressed as 100 .

\section{Modification of the host cell surface}

The effect of modifying the surface carbohydrates of buccal epithelial cells is shown in Table 4. The binding of the $\mathrm{P}^{-}$variant was unaffected by any of the treatments of buccal epithelial cells. By contrast, attachment of the $\mathrm{P}^{++}$variant to buccal epithelial cells pretreated with a mixture of exoglycosidases was dramatically decreased to a level below that found for the $\mathrm{P}^{-}$variant. However, modification of buccal epithelial cell surface carbohydrates by treatment with neuraminidase or periodate oxidation followed by borohydride reduction failed to decrease the attachment of the $\mathrm{P}^{++}$variant.

Modification of the erythrocyte surface presented a somewhat different picture (Table 5). Removal of sialic acid residues with neuraminidase or removal of surface glycoprotein with trypsin enhanced the binding of the $\mathrm{P}^{-}$variant to the same level as the $\mathrm{P}^{++}$variant. In contrast to the buccal epithelial cells, periodate oxidation of the erythrocyte surface resulted in a decreased attachment of the $\mathrm{P}^{++}$variant to the level obtained for the $\mathrm{P}^{-}$strain.

\section{DISCUSSION}

Gonococci infecting mucosal surfaces exist in a complex environment rich in mucins and varying in ionic composition. The $\mathrm{pH}$ optimum ( $\mathrm{pH} 6$ to 7 ) for attachment of $\mathrm{P}^{++}$gonococci to buccal epithelial cells is appropriate to the preferred sites of infection in the urethra and endocervix. In women during the menstrual cycle the $\mathrm{pH}$ of endocervical mucus varies from 5.9 to 7.3 (Kroeks \& Kremer, 1977) while the urethra may be flushed with urine with a pH range of 4.8 to $8 \cdot 0$ and, in men, prostatic secretions at a $\mathrm{pH}$ of $6 \cdot 45$. By contrast, the squamous lining of the vagina which is immune to gonococcal infection is bathed with acid secretions ranging in pH from $3 \cdot 5$ to 5.3. Mardh \& Weström (1976) reported that gonococcal attachment to vaginal epithelial cells was enhanced threefold at $\mathrm{pH} 4.5$ compared to $\mathrm{pH} 7.5$, while Pearce \& Buchanan (1978) showed comparable increases in the binding of purified, 
radio-iodinated pili to buccal epithelial cells. Recent work in this laboratory (Lambden et al., 1980) has shown that two distinct types of pili produced by variants of a single strain of gonococcus $\mathrm{P9}$ differ markedly in their $\mathrm{pH}$ optima for attachment to buccal epithelial cells. Whether pili with differing binding optima are important in gonococcal adhesion to different mucosal surfaces is unknown but there is now evidence of phenotypic change in gonococci induced by the physiological conditions of the host, for example, change in outer membrane composition induced by female sex hormones and proteases (James \& Swanson, 1978).

Unlike the adhesion to epithelial cells, the attachment of $\mathrm{P}^{++}$gonococci to erythrocytes was unaffected by $\mathrm{pH}$ over the range $4 \cdot 5$ to $7 \cdot 5$. This suggests differences in the mechanism of attachment of these cell types. One possibility is that the erythrocyte membrane, which is significantly different from that of other cells in the absence of HLA antigens (Barnstable et al., 1978), lacks receptors for gonococcal pili. Certainly, gonococcal pili readily bind to non-specific surfaces such as polystyrene and, like adhesion to cell membranes, this attachment is temperature-dependent (Buchanan, 1978). Further, the suggestion that pili serve to penetrate the electrostatic repulsive barrier between the negatively charged surfaces of the gonococcus and host cell membranes (Heckels et al., 1976) is consistent with the finding that removal of charged groups from the erythrocyte surface by treatment with trypsin or neuraminidase increases the binding of $\mathrm{P}^{-}$gonococci to the same value as $\mathrm{P}^{++}$gonococci. In this case, adhesion of $\mathbf{P}^{-}$gonococci to the modified erythrocyte surface must be due to other surface components such as outer membrane protein I or LPS. There is evidence to suggest that the adhesion of Salmonella typhimurium to macrophages results from the interaction of sugar residues on the bacterial LPS with 'receptors' on the host cell surface (Freimer et al., 1978). This adhesive mechanism does not apply to gonococcal epithelial cell interactions since the gonococcal core oligosaccharide-methyl-BSA complex does not attach either to erythrocytes (results not presented) or buccal epithelial cell membranes. The non-specific nature of the attachment of $\mathrm{P}^{-}$gonococci to erythrocyte surfaces is further supported by the finding that variants possessing additional outer membrane proteins show specific adhesion to epithelial cells but impaired binding to erythrocytes (Lambden et al., 1979).

The importance of hydrophobic interaction in gonococcal attachment could not be assessed using currently available methods. The usual technique of hydrophobic interaction chromatography permits bacteria to bind to the gel in the presence of $1 \mathrm{M}$-ammonium sulphate and then measures the elution profile on stepwise reduction in the concentration of ammonium sulphate while increasing the concentration of Triton X-100 from 0 to $0 \cdot 1 \%$ (v/v) (Stjernström et al., 1977). Unfortunately, the outer membrane of gonococci is extremely fragile and using ${ }^{3} \mathrm{H}$-labelled gonococci we have shown that the eluate consists of solubilized gonococcal components and not intact organisms. The alternative approach of partition in an aqueous two-phase system consisting of $4.4 \%(\mathrm{w} / \mathrm{w})$ polyethylene glycol 600 and $6.2 \%(\mathrm{w} / \mathrm{w})$ Dextran T500 (Stendahl et al., 1973) could not be applied to gonococci since polyethylene glycol causes aggregation of gonococcal pili (unpublished observations). The simple technique described here permitted comparison of the relative hydrophobicity of gonococcal variants at ionic concentrations comparable to those on mucosal surfaces. The binding of gonococci to the amphipathic gels showed a direct relationship between gonococcal binding and the length of the alkyl substituent from agarose $\mathrm{C}_{0}$ to $\mathrm{C}_{10}$. The concentration of alkyl groups is comparable on all gels [0.2 mol substituent (mol galactose) ${ }^{-1}$; manufacturers' data] suggesting that lipophilic interaction between the gonococcal surface and the hydrocarbon chains accounts for the marked increase in binding to agarose $C_{6}, C_{8}$ and $C_{10}$.

These results clearly establish that the outer membranes of gonococci possess hydrophobic pockets or regions capable of interactions with any like groups on host cell membranes. Further, pili confer minimal advantages in binding to agarose $\mathrm{C}_{6}, \mathrm{C}_{8}$ or $\mathrm{C}_{10}$. This finding is in marked contrast to the report that the pilus-like $\mathrm{K} 88$ antigen was solely responsible for the binding of smooth Escherichia coli to amphipathic gels (Smyth et al., 1978). The adhesion 
of the gonococcal outer membrane to the mucosal cell surface occurs in an aqueous environment; the exclusion of hydrophobic groups from the water lattice will facilitate close approximation of hydrophobic surfaces permitting bonding by London-van der Waals' forces.

Treatment of buccal epithelial cells with an exoglycosidase mixture decreased pilusmediated adhesion to $22 \%$ of the control value. Although we cannot exclude pilus-mediated binding to a single sugar with a unique conformation, this is unlikely because adhesion was unaffected by the presence of the constituent sugars of cell surface glycolipids and glycoproteins. One explanation may be that the pilus receptor is a polysaccharide with a specific glycosidic linkage, or a combination of sugars, surface protein and lipids. Such a surface structure may not necessarily be altered by periodate oxidation or treatment with neuraminidase which is presumably the case for buccal epithelial cells. Also, the $\mathrm{P}^{++}$strain clearly demonstrated enhanced aggregation in the presence of the ganglioside GT1 indicating a possible role for this glycolipid in the attachment mechanism. Clearly, future attempts to elucidate the molecular basis of gonococcal attachment will be complicated by the ability of gonococci to bind non-specifically, for example by hydrophobic interactions, to cell surfaces.

This work was supported by a Medical Research Council Programme Grant.

\section{REFERENCES}

Barnstable, C. J., Jones, E. A. \& Crumpton, M. J. (1978). Isolation, structure and genetics of HLA-A, -B, -C and DRw (Ia) antigens. British Medical Bulletin 34, 241-246.

BuchanaN, T. M. (1977). Surface antigens: pili. In The Gonococcus, pp. 255-273. Edited by Richard B. Roberts. New York: John Wiley.

Buchanan, T. M. (1978). Antigen-specific serotyping of Neisseria gonorrhoeae. I. Use of an enzyme-linked immunosorbent assay to quantitate pilus antigens on gonococci. Journal of Infectious Diseases 138, 319-325.

DiRienzo, J. M., Nakamura, K. \& Inouye, M. (1978). The outer membrane proteins of gramnegative bacteria: biosynthesis, assembly and functions. Annual Review of Biochemistry 47, 481-532.

Dubois, M., Gilles, K. A., Hamilton, J. K., Rebers, P. A. \& SMITH, F. (1956). Colorimetric method for the determination of sugars and related substances. Analytical Chemistry 28, 350-356.

Freimer, N. B., ÖGMUNDSdótTIR, H. M., BlaCKWELl, C. C., Sutherland, I. W., Graham, L. \& WEIR, D. M. (1978). The role of cell wall carbohydrates in binding of microorganisms to mouse peritoneal exudate macrophages. Acta pathologica et microbiologica scandinavica B86, 53-57.

Greenwood, F. C., Hunter, W. M. \& Glover, J. S. (1963). The preparation of ${ }^{131}$ I-labelled human growth hormone of high specific radioactivity. Biochemical Journal 89, 114-123.

HeCKeLS, J. E. (1977). The surface properties of Neisseria gonorrhoeae: isolation of the major components of the outer membrane. Journal of General Microbiology 99, 333-341.

Heckels, J. E., BlacketT, B., Everson, J. S. \& WARD, M.E. (1976). The influence of surface charge on the attachment of Neisseria gonorrhoeae to human cells. Journal of General Microbiology 96, 359-364.

JAMES, J. F. \& Swanson, J. (1978). Color/opacity colonial variants of Neisseria gonorrhoeae and their relationships to the menstrual cycle. In Immunobiology of Neisseria gonorrhoeae, pp. 338343. Edited by G. F. Brooks, E. C. Gotschlich, K. K. Holmes, W. D. Sawyer \& F. E. Young. Washington, D.C.: American Society for Microbiology.

KroeKs, M. V. A. M. \& KREMER, J. (1977). The pH in the lower third of the genital tract. In The Uterine Cervix in Reproduction, pp. 109-117. Edited by V. Insler \& G. Bettendorf. Stuttgart: Thieme.

Lambden, P. R., Heckels, J. E., James, L. T. \& WATT, P. J. (1979). Variations in surface protein composition associated with virulence properties in opacity types of Neisseria gonorrhoeae. Journal of General Microbiology 114, 305-312.

LAMBDEN, P. R., Robertson, J. N. \& WATt, P. J. (1980). Biological properties of two distinct pilus types produced by isogenic variants of Neisseria gonorrhoeaea P9. Journal of Bacteriology 141, 393-396.

MÅRDH, P.-A. \& Weström, L. (1976). Adherence of bacteria to vaginal epithelial cells. Infection and Immunity 13, 661-666.

Pearce, W. A. \& Buchanan, T. M. (1978). Attachment role of gonococcal pili, optimum conditions and quantitation of adherence of isolated pili to human cells in vitro. Journal of Clinical Investigation 61, 931-943.

Perry, M. B., Daoust, V., Diena, B. B., Ashton, F. E. \& Wallace, R. (1975). The lipopolysaccharides of Neisseria gonorrhoeae colony types 1 and 4. Canadian Journal of Biochemistry 53, 623-629. 
SMYTH, C. J., Jonsson, P., OlsSon, E., Sönderlind, O., Rosengren, J., HJertén, S. \& WadströM, T. (1978). Differences in hydrophobic surface characteristics of porcine enteropathogenic Escherichia coli with or without $\mathrm{K} 88$ antigen as revealed by hydrophobic interaction chromatography. Infection and Immunity 22, 462-472.

Stendahl, O. C., Tagesson, C. \& Edebo, M. (1973). Partition of Salmonella typhimurium in a twopolymer aqueous phase system in relation to liability to phagocytosis. Infection and Immunity 8, 36-41.

StJernström, I., Magnusson, K.-E., Stendahl, O. \& TAGESson, C. (1977). Liability to hydrophobic and charge interaction of smooth Salmonella typhimurium 395MS sensitised with anti-MS immunoglobulin $\mathrm{G}$ and complement. Infection and Immunity 18, 261-265.

WaravdeKaR, V.S. \& SaSlaw, L. D. (1959). A sensitive colorimetric method for the estimation of 2-deoxy sugars with the use of the malonaldehyde-thiobarbituric acid reaction. Journal of Biological Chemistry 234, 1945-1950.

Ward, M. E., Lambden, P. R., Heckels, J. E. \& WATT, P. J. (1978). The surface properties of Neisseria gonorrhoeae: determinants of susceptibility to antibody complement killing. Journal of General Microbiology 108, 205-212. 